\title{
Radicalisering in Molenbeek
}

\section{Belgisch tweesporenbeleid verhindert integrale aanpak*}

\author{
Elke Devroe \& Paul Ponsaers
}

\section{Inleiding}

Gedurende de avond van 13 november 2015 vindt een reeks van moorddadige aanslagen plaats in Parijs. Tijdens de aanslagen vallen 130 doden en 350 gewonden. Amper enkele maanden later, op 22 maart 2016, vinden in Brussel twee bomaanslagen plaats. Hier worden 35 dodelijk slachtoffers en 340 gewonden genoteerd. Tussen beide aanslagenreeksen zijn verschillende verbindende elementen. Eén hiervan is zonder enige twijfel de betrokkenheid van verdachten afkomstig uit de Brusselse gemeente Molenbeek.

In dit artikel willen we ingaan op de centrale vraag: Waarom neemt precies Molenbeek zo'n centrale plaats in het terreurdossier in en op welke wijze kan hieraan geremedieerd worden?

Een eerste deel beschrijft de gemeente Molenbeek als zodanig en de radicaliseringstendensen die zich gedurende de voorafgaande jaren voordeden in deze Brusselse gemeente. Er zal vastgesteld worden dat Molenbeek een erg moeilijke periode doormaakte gedurende het afgelopen decennium, dat de gemeente bij herhaling met het radicaliseringsprobleem werd geconfronteerd en in een neerwaartse spiraal terechtkwam. Nochtans zal opgemerkt worden dat niet zozeer het recherche- en gerechtelijk apparaat faalde in de strijd tegen het terrorisme. Bij herhaling werden immers grote groepen verdachten voor de rechter gebracht en veroordeeld. Het zal echter blijken dat dit niet heeft kunnen verhinderen dat een aantal onder hen verder radicaliseerde en betrokken raakten bij terreurdaden. De stelling die hier wordt verdedigd, is dan ook dat niet zozeer de strafrechtelijke aanpak faalde, maar dat deze aanpak alleen onvoldoende was. Het is het bestuurlijk kader dat te gebrekkig werkte om radicalisering tegen te houden.

In het navolgende gedeelte van dit artikel wordt dan ook een structurele diagnose gemaakt van de bestuurlijke context waarbinnen Molenbeek binnen het Brussels Hoofdstedelijk Gewest functioneert en hoe de politiële aanpak hier al dan niet op aansluit. Hier wordt vastgesteld dat vooral de afstemming tussen het preventief-

* Prof. Elke Devroe is Associate Professor aan het Institute of Security and Global Affairs (ISGA), Faculteit Governance and Global Affairs van de Universiteit Leiden.

Prof. dr. em. Paul Ponsaers is werkzaam bij de Vakgroep Strafrecht, Criminologie en Sociaal Recht van de Rechtsfaculteit van de Universiteit Gent. 
bestuurlijk luik enerzijds en het repressief-gerechtelijk luik anderzijds structurele gebreken vertoont, die niet langer kunnen worden teruggebracht tot individuele tekorten, maar eerder toe te schrijven zijn aan de breuklijnen die het land (politiek en taalkundig) verdelen en in grote mate een goede afstemming tussen beide soorten van aanpak in de weg staan. Het gaat om constructiefouten die dringend om remediëring vragen.

Deze bijdrage richt zich tot de Nederlandse lezer die minder vertrouwd is met de Belgische staatsconstructie. Ze is in grote mate gesteund op mediaberichtgeving. Bij gebrek aan andere bronnen was dit onvermijdelijk.

\section{Molenbeek als broedplaats van jihadisme}

Molenbeek, voluit eigenlijk Sint-Jans-Molenbeek, kreeg afgelopen jaren in toenemende mate te maken met opvallende radicalisering van jongeren op haar grondgebied. Dit proces kende een historische ontwikkeling in verschillende fasen, waarvan de ernst toenam. Het is hier niet de plaats om gedetailleerd in te gaan op de achtergronden van alle betrokkenen in de aanslagenreeksen van Parijs en Brussel, en hun verbanden met Molenbeek. We stellen echter vast dat voordat de beide aanslagenreeksen zich voordeden, er reeds drie opvallende signalen waren die telkens weer verwezen naar Molenbeek als broedplaats van radicalisering en terrorisme. Het gaat met name om de groep Sharia4Belgium, het keldermoskeenetwerk en de Verviers-cel. In het navolgende wordt hiervan een beeld gegeven, nadat eerst een korte schets van de gemeente Molenbeek wordt gegeven. We sluiten dit deel af met een tussentijdse bedenking die ons leidt naar deel twee van deze bijdrage, op zoek naar een antwoord op de centrale vraagstelling van dit artikel.

\subsection{De gemeente Molenbeek}

Molenbeek is een van de negentien gemeenten van het Brussels Hoofdstedelijk Gewest. Op 1 februari 2016 telde de gemeente 95.576 inwoners, met een gemiddelde leeftijd van 34 jaar en 10 maanden en spreidt zich uit over een oppervlakte van 5,9 km2. Afgelopen jaren deed zich in de gemeente een sterke bevolkingsgroei voor. ${ }^{1}$ Dat is het gevolg van een hoog natuurlijk saldo (met andere woorden een hoog geboortecijfer en een laag sterftecijfer, omdat het aandeel jonge - uit het buitenland ingeweken inwoners - bijzonder groot is). Op de tweede plaats heeft de gemeente te kampen met een grote instroom van immigrerende nieuwkomers. ${ }^{2}$ Verder wordt een zeer hoge werkloosheidsgraad vastgesteld. Deze is onder de jeugd een van de hoogste van Europa. De gemeente kent een laag opleidingsniveau, een verouderd woonbestand, heeft een grote behoefte aan voorzieningen qua gezondheid, onderwijs en cultuur, een gebrek aan groene ruimten, en

1 P. Deboosere e.a., 'Staten-Generaal van Brussel. De Brusselse bevolking: een demografische doorlichting', Brussels Studies, Synthesenota 2009, 3.

2 J. Leman, 'De sociale problematiek in Molenbeek en het gewelddadig jihadisme', Cahiers Politiestudies 2016, 42. 
vooral een gebrek aan stedelijke cohesie als gevolg van de wegtrekkende industrie. $^{3}$

Molenbeek ligt langs het kanaal Antwerpen-Brussel-Charleroi. ${ }^{4}$ Het kanaal is op de meeste plaatsen een breuklijn waar de groeiende sociale kloof aan de oppervlakte komt, een muur die het gewest doormidden snijdt in twee gescheiden werelden. Het betekent als het ware een scheidingslijn tussen de trendy cafés van het stadscentrum en de volkse migrantenbuurten van Oud Molenbeek.

Toen onze onderzoeksgroep in 2012 in de kanaalzone onderzoek verrichtte naar aanleiding van een aantal ernstige ordeverstoringen, viel het ons inderdaad reeds op dat de bevolking een dermate groot verloop kende dat het nauwelijks mogelijk was voor de wijkinspecteurs om op te volgen wie precies waar woont. ${ }^{5}$ Domiciliecontroles bleken een haast onmogelijke opdracht. Het gaat om een erg 'vlottende en tijdelijke bevolking' in algemene zin, een probleem dat vooral te maken heeft met de demografische (erg diverse) samenstelling van de bevolking. Het hoeft dan ook niet vermeld dat de sociale cohesie (en bijhorende sociale controle) hieronder fel te lijden heeft.

Het aantal kiezers in verhouding tot het aantal inwoners ligt in Molenbeek erg laag, zowel absoluut als in vergelijking met de rest van het land. Dit is het gevolg van het hoge aandeel niet-Belgische inwoners (ook al kunnen deze onder bepaalde voorwaarden over gemeentelijk stemrecht beschikken). ${ }^{6}$ Daarnaast ligt ook het aantal kiezers dat - ondanks de stemplicht - niet komt opdagen erg hoog. Het totaal aantal uitgebrachte stemmen bedraagt slechts $41,91 \%$ van het aantal inwoners.

Vanuit politiek oogpunt werd de gemeente afwisselend bestuurd door een Franstalige liberale, dan weer een socialistische burgemeester. Voordat de huidige coalitie aantrad, was de Franstalige socialist (PS) Philippe Moureaux, meer precies van 1993 tot 2012, burgemeester, een functie die hij bij herhaling combineerde met een parlementair mandaat. ${ }^{7}$ Moureaux was vergroeid met 'zijn' gemeente en genoot - als voormalig minister van Justitie - algemene erkenning als groot staatsman. In 1981 werd de antiracismewet door hem ingediend in het federaal

3 E. Corijn, 'Brussel, een kosmopolitische stad ... in wording', in: M. van de Bossche \& B. Lleshi (red.), Identiteit en interculturaliteit: Identiteitsconstructie bij jongeren in Brussel, Brussel: VUB Press 2010.

4 Dat kanaal loopt van noord naar zuid door het Brusselse gewest langs de westgrens, naast het historische centrum. De kanaalzone strekt zich over een afstand van $14 \mathrm{~km}$ uit. De kanaalzone komt grotendeels overeen met de negentiende-eeuwse industriebuurten. In de twintigste eeuw is de oude industrie er echter grotendeels verdwenen, zodat op vele plaatsen een verwaarloosd industrieel erfgoed, veel leegstand en een fragiel sociaaleconomisch netwerk zijn overgebleven.

5 C. Liedenbaum e.a., De Wijk achter de Botsing - Een Onderzoek naar Wijken in Nederland en België met ernstige Ordeverstoringen (Reeks Politiestudies, nr. 7), Antwerpen/Apeldoorn: Maklu 2013.

6 B. Wayens e.a., Gemeentelijke fiches voor de analyse van lokale statistieken in het Brussels Gewest, Gemeente Sint-Jans-Molenbeek, 2010, te raadplegen via: www.observatbru.be.

7 Raadpleeg voor meer informatie omtrent de politieke carrière van Philippe Moureaux de website van de Senaat: http://senat.be/www/?MIval=/showSenator\&ID=208\&LANG=fr. 
parlement en op zijn initiatief gestemd. In 2004 was hij als senator medeauteur van het wetsontwerp tot toekenning van het actief kiesrecht bij de gemeenteraadsverkiezingen aan vreemdelingen. Het vertrek van Moureaux als burgemeester in Molenbeek verliep niet zonder slag of stoot, aangezien zijn fractie bij de gemeenteraadsverkiezingen van 2012 wel de grootste bleef, maar ten gevolge van de coalitiebesprekingen uit de boot viel. De wissel van burgemeesterssjerp viel hij dan ook fel aan. Hij beschouwde de huidige coalitie tussen MR (Franstalige liberalen), Open Vld (Nederlandstalige liberalen), CD\&V (Nederlandstalige christendemocraten), cdH (Franstalige christendemocraten), Ecolo (Franstalig) en Groen (Nederlandstalig) als een coalitie tégen de PS (Parti Socialiste) ${ }^{8}$

Als nieuw burgemeester trad Françoise Schepmans (MR) aan. Na de terroristische aanslagen in Parijs in november 2015, waarbij meerdere terroristen banden bleken te hebben met Molenbeek, werd Moureaux verweten dat hij te weinig had gedaan om de radicalisering in zijn gemeente terug te dringen. Moureaux reageerde hierop met de publicatie van een boek waarin hij de verdediging opnam van de gestigmatiseerde Molenbeekse bevolking en beklemtoonde dat die in grote meerderheid terreur verwerpt en afkeurt. Hij wees er verder op dat het radicaliseringsprobleem Molenbeek ver overstijgt. Voor hem is het radicalisme een erg complex probleem dat niet meteen opgelost zal geraken en een aanpak van de verschillende beslissingsniveaus vereist. Hij stelt echter vast dat die gezamenlijke aanpak niet aanwezig is. Moureaux rekent in zijn slothoofdstukken scherp af met de huidige burgemeester en de huidige minister van Binnenlandse Zaken. ${ }^{9}$

\subsection{Molenbeek als broedplaats?}

Molenbeek kwam vóór de novemberaanslagen in Parijs en de maartaanslagen in Brussel reeds bij herhaling in de belangstelling, juist omwille van het verband met radicalisering. Globaal kan gesteld worden dat de gemeente in een neerwaartse spiraal terechtkwam, waarbij provocaties en ordeverstoring escaleerden tot daadwerkelijke vormen van terrorisme. Drie belangrijke fasen hierin worden kort geschetst.

(1) Op 3 september 2010 wordt Sharia4Belgium opgericht. Na een reeks van incidenten wordt de beweging eind 2012 ontbonden. Op 29 september 2014 gaat er in Antwerpen een proces van start tegen 45 leden van de vereniging, in navolging

8 De burgemeester in België wordt door de gewestregering benoemd uit de leden van de gemeenteraad voor een periode van zes jaar. In die zin vloeit het burgemeesterschap (meestal) voort uit de lokale verkiezingen en de daaropvolgende coalitiebesprekingen. Hij staat aan het hoofd van de gemeentelijke administratie en is meestal voorzitter van de gemeenteraad en het college van burgemeester en schepenen. Nederlandse burgemeesters stellen hun kandidatuur in antwoord op een officiële vacature die gepubliceerd wordt door de minister van Binnenlandse Zaken en Koninkrijksrelaties. Eens de commissaris van de Koning hen selecteert als potentiële kandidaat doorloopt hij een formele procedure, inclusief interviews met een selectie van gemeenteraadsleden. Nederlandse burgemeesters worden verondersteld boven de politiek te staan en als hoeders te fungeren van de kwaliteit en het resultaat van de lokale besluitvorming. Samengevat is het mandaat van burgemeester in België dan ook veel politieker van aard dan in Nederland. 
van een grootschalige antiterreuractie waarbij politie en gerecht 48 huiszoekingen verrichtten. Er staan 45 verdachten terecht, van wie er slechts negen komen opdagen. ${ }^{10}$ De rest laat verstek gaan. Op 11 februari 2015 velt de rechtbank haar vonnis. $^{11}$

De rechtbank stelt in haar vonnis vast dat de groep de intentie had terroristische misdrijven te plegen. De leider van Sharia4Belgium en zijn volgelingen hebben zich volgens de rechtbank overduidelijk bezondigd aan georganiseerde beïnvloeding van jongeren. Jongeren werden mentaal en fysiek voorbereid op de gewapende strijd. De jongeren veranderden qua mentaliteit en kleding. Ze werden gedwongen te stoppen met school, moesten een nieuwe naam aannemen en de organisatie kwam tussen bij de keuze van hun huwelijkspartners. De rechtbank stelde verder vast dat de grote meerderheid van de beklaagden vertrok naar Syrië en zich daar aansloot bij Jabhat al-Nusra. ${ }^{12}$ Velen van hen stierven intussen in de gewapende strijd.

Uit het vonnis blijkt dat leden van Sharia4Belgium, met standplaats in Antwerpen en met overwegend Antwerpse leden, bij herhaling Molenbeek viseerden als de plaats bij uitstek om tot ordeverstoring over te gaan. Zo is er een aantal betrokken bij het zogenoemde 'theehuisincident' (een hardhandig treffen met de politie van Molenbeek), bij het 'nikab-incident' (waarbij een vrouw werd opgepakt omdat ze haar nikab weigerde af te doen, hetgeen aanleiding gaf tot onlusten en relletjes in Molenbeek gedurende weken), en bij een aanval op het commissariaat in Molenbeek. Blijkbaar oefende Molenbeek toen reeds (het gaat om feiten die zich voordoen in de periode 2010-2012) een aantrekkingskracht uit voor radicaliserende jongeren.

Maar vandaag, na de aanslagen in Parijs en Brussel, weten we meer. Een voormalig (en veroordeeld lid) van Sharia4Belgium liet zich in juni 2013 fotograferen met leden van Katiba Al-Battar. ${ }^{13}$ Het is dezelfde persoon die in augustus 2015 dreigementen uitte tegen België en via WhatsApp berichten verzond naar academicus Montasser AIDe'emeh, auteur van het boek De Jihadkaravaan. ${ }^{14}$ Hij schrijft aan de onderzoeker: 'Dit is geen bedreiging of wat dom gepraat. Dit is een oorlogsverklaring en de plannen zijn al gesmeed. Alles gaat in de lucht in België. Bibliotheken, scholen, ziekenhuizen, winkelstraten, discotheken (...) Alle plaatsen waar er onge-

10 F. Bruggeman \& G. Paelinck, 'Maar negen beklaagden aanwezig op eerste procesdag Sharia4Belgium', De Redactie.be 29 september 2014, te raadplegen via: http://deredactie.be/cm/vrtnieuws/ binnenland/1.2104413.

11 J. Lambrecht, IS: het nieuwe terrorisme van Daesh en de ondergang van de Moslimbroederschap, Leuven: Van Halewijck 2015.

12 Jabhat al-Nusra werd in januari 2012 opgericht als een onderafdeling van de Islamitische Staat in Irak (ISI), het voormalige Al Qaida in Irak en de latere Islamitische Staat. De groep hangt een ideologie aan die de strijd voor de islam voor ogen heeft, met de stichting van een kalifaat als einddoel.

13 Het gaat om een elitebrigade, Katiba Al-Battar; de Brigade van het zwaard van de Profeten geldt als de militaire ruggengraat van IS en wordt door Libiërs geleid.

14 M. AlDe'emeh \& P. Stockmans, De Jihadkaravaan. Reis naar de wortels van de haat, Tielt: Lannoo 2015. 
lovigen zijn. Wij houden geen rekening meer met al dat gepraat over onschuldige slachtoffers. Alle ongelovigen worden vermoord. Wij doden hen zoals zij ons doden. Begrepen?'15

$\mathrm{Na}$ de Brusselse aanslagen van 22 maart 2016 zal een ander toenmalig veroordeelde aanhanger van Sharia4Belgium twee videoboodschappen verspreiden vanuit Syrië, waarin hij van de Belgische regering eist zich terug te trekken uit het Midden-Oosten. Op 8 april 2016 wordt overigens een van de veroordeelde leden van Sharia4Belgium opgepakt in Brussel omwille van betrokkenheid bij de Brusselse aanslagen. ${ }^{16}$

Kortom, gedurende de periode 2010 en 2012 was Molenbeek reeds het geprefereerde doelwit van radicaliserende jongeren. De Belgische justitie en politie hebben hieraan trachten te remediëren door een gerechtelijk onderzoek te starten en een proces te voeren tegen de leiding en de brede groep van sympathisanten van Sharia4Belgium. De veroordelingen volgden weliswaar, maar er bleken slechts 9 van de 45 personen aanwezig te zijn op het proces en de straffen konden niet voorkomen dat verschillende betrokkenen België verlieten, afreisden naar Syrië als foreign fighters en later als returnees terugkeerden naar ons land. De louter strafrechtelijke aanpak had dan wel een juridische realiteit gecreëerd, maar bleek weinig effect te hebben gehad op het radicaliseringstraject van verschillende leden.

(2) Een tweede belangrijke fase in het Molenbeekse radicaliseringsproces houdt verband met het zogenoemde keldermoskee-netwerk. ${ }^{17}$ Vanaf april 2012 zal de leider van het netwerk ( $Z$, een Marokkaan uit Molenbeek) jongeren rekruteren om de strijd te gaan voeren in Syrië en Irak. De man deed dat zowel in sportclubs als in zogeheten 'keldermoskeeën', geïmproviseerde gebedsplaatsen waar hij zijn toehoorders overtuigde om de wapens op te nemen. Hij opereerde vooral in de Maritieme Wijk (in de kanaalzone) in Molenbeek. De wijk staat bekend om zijn illegale drugshuizen die schuilgaan achter culturele verenigingen.

In april 2012 maakte de Belgische Veiligheid van de Staat (vergelijkbaar met de Nederlandse Algemene Inlichtingen- en Veiligheidsdienst) een nota over aan het parket over het keldermoskee-netwerk. Later zal deze nota deel uitmaken van het gerechtelijk dossier tegen de groep rond Z. De nota gaat over verdachte bijeenkomsten in een appartement in Molenbeek. Volgens deze nota werd er tijdens de bijeenkomsten gepraat over de noodzaak om gewapende aanvallen uit te voeren op de 'voornaamste tegenstander van de islam', in casu de westerse democratie.

15 R.R. Belga, 'IS stuurt nieuw dreigement naar België: "Alles gaat de lucht in. Bibliotheken, scholen, ziekenhuizen"', Knack 20 augustus 2015.

16 R.R. Belga, 'Veroordeelde Sharia4Belgium is zesde terreurverdachte', Het Laatste Nieuws 9 april 2016, te raadplegen via: www.hln.be/hln/nl/36484/Aanslagen-Brussel/article/detail/2670944/ 2016/04/09/Ook-veroordeelde-Sharia4Belgium-proces-opgepakt-als-terreurverdachte.dhtml.

17 M. Eeckhaut, 'Khalid Zerkani, de Kerstman die ronselde voor Syrië', De Standaard 7 mei 2015, te raadplegen via: www.standaard.be/cnt/dmf20150506_01667608. 
Plannen werden, aldus de nota, gesmeed om zware wapens en explosieven te bekomen om aanslagen uit te voeren. ${ }^{18}$

In 2014 wordt Z. gearresteerd en eind februari van dat jaar wordt het netwerk rond de man opgerold. Tijdens de week van 21 tot 28 februari worden in elf politiezones 55 huiszoekingen doorgevoerd en 74 personen ondervraagd in het kader van deze grootschalige actie. Z. zou zijn ronselpraktijken tot in de gevangenis hebben voortgezet, reden waarom hij in isolement werd geplaatst. Op 29 juli 2015 staat het netwerk terecht. 32 personen worden in beschuldiging gesteld. Naast Z. staan ook personen terecht die ook Syrië-strijders ronselden of hen hielpen bij het vertrek. Anderen vertrokken dan weer naar Syrië of stonden op het punt om dat te doen. De leider van het netwerk wordt tot twaalf jaar cel veroordeeld.

Vandaag weten we dat het appartement waar de bijeenkomsten van het keldermoskee-netwerk doorgingen, eigendom was van een man die later naar Syrië reisde, samen met een van de toekomstige zelfmoordterroristen in Parijs tijdens de novemberaanslagen in 2015. Daarenboven weten we nu dat een van de veroordeelden (uit Molenbeek) in de zaak van het netwerk (hij werd veroordeeld tot twintig jaar celstraf bij verstek) zal ontmaskerd worden als de organisator van de aanslagen in Parijs in november 2015. Een andere bij verstek veroordeelde, eveneens uit Molenbeek, zal in verdenking gesteld worden van het maken van de bomgordels die gebruikt werden bij dezelfde Parijse aanslagen. Ook de man uit Schaarbeek, die de bommen maakte voor de maartaanslagen in Brussel (en zichzelf op Zaventem-luchthaven opblies), behoorde tot het keldermoskee-netwerk. ${ }^{19}$

Uit deze zaak kan worden afgeleid dat gedurende de periode 2012 en 2014 niet enkel jongeren actief werden geradicaliseerd in Molenbeek, maar dat een belangrijke aanzet werd gegeven om hen te betrekken bij de gewapende strijd in Syrië. Het keldermoskee-netwerk fungeerde eveneens als terugkeerbasis van returnees uit het Syrisch oorlogsgebied, om in Europa terroristische aanslagen voor te bereiden. Opnieuw hebben de Belgische justitie en politie getracht het fenomeen een halt toe te roepen door een brede groep te veroordelen, maar ook dit keer is het duidelijk dat dit gebeurde in afwezigheid van de belangrijkste betrokkenen, die zich onttrokken aan het gerecht en vrijwel ongehinderd tussen Syrië en Europa reisden. Opnieuw had de louter strafrechtelijke aanpak tot veroordelingen geleid, maar met weinig effect op het radicaliseringsproces van vele betrokkenen.

(3) Een week na de Charlie Hebdo-aanslagen in Parijs van 7 januari 2015 doet de Belgische politie op 15 januari een inval in een safehouse in Verviers. De oprichter Nieuws 26 januari 2016, te raadplegen via: www.hln.be/hln/nl/35524/Aanslagen-Parijs/article/ detail/2596955/2016/01/26/Staatsveiligheid-Weinig-hints-naar-aanslagen-Parijs-in-terreurnota. dhtml.

19 AFP, 'Terrorisme: Khalid Zerkani, mentor de Kriket, Abaaoud et Laachraoui', Le Point 25 maart 2016, te raadplegen via: www.lepoint.fr/monde/terrorisme-khalid-zerkani-mentor-de-kriketabaaoud-et-laachraoui-25-03-2016-2028008_24.php. 
van de cel, dezelfde veroordeelde man uit het keldermoskee-netwerk uit Molenbeek, zal later blijken de coördinator te zijn van de novemberaanslagen in Parijs. Uit de berichtgeving die het Belgische federaal parket verspreidt naar aanleiding van de politie-interventie in Verviers, blijkt dat hij een aanslag wilde plegen met zijn cel in Brussel op politiekantoren, meer precies op het commissariaat van de politie van Molenbeek en het hoofdkwartier van de federale politie in Brussel. De antiterreuractie die in Verviers werd gehouden, was onderdeel van een internationale operatie waarbij zeven landen betrokken waren. Twee mannen werden neergeschoten tijdens de operatie door de politie, één werd gearresteerd. De centrale coördinator uit Molenbeek weet te ontkomen, waardoor hij later in de mogelijkheid zal zijn om de novemberaanslagen in Parijs te organiseren.

De officiële woordvoerder van IS legt naderhand een verklaring af vanuit Syrië. 'Jullie zagen wat onze broeders daar hebben gedaan. Moge Allah hen genadig zijn en hen belonen.' Enkele uren na de boodschap verschijnt er een tweet die een foto bevat van de twee doden in Verviers, samen met de coördinator uit Molenbeek, tijdens hun verblijf aan het front in Syrië. De coördinator schept zelf op in het ISinternet propagandatijdschrift Dabiq: 'Na een vuurgevecht van 10 minuten, zijn mijn broeders gezegend met het martelaarschap, zoals zij al zo lang wensten. $\mathrm{Na}$ de raid kregen de inlichtingendiensten door dat ik de broeders had bezocht en dat we samen bezig waren geweest plannen te maken voor acties. ${ }^{20}$

In juli 2016 stonden zestien leden terecht voor de correctionele rechtbank van Brussel en werden gestraft van dertig maanden tot zestien jaar. Negen ervan waren voortvluchtig, internationaal geseind en werden bij verstek veroordeeld. Velen zijn afkomstig uit Molenbeek, anderen hebben de Franse, Nederlandse of Marokkaanse nationaliteit. Ondanks de pertinente inspanningen van politie en gerecht om de aanslagen die beraamd werden in Verviers te voorkomen (onder meer een aanslag op de luchthaven van Zaventem), kon het gerecht niet voorkomen dat een hele generatie geradicaliseerden in het buitenland klaargestoomd werd om naar Europa terug te keren als volleerde terroristen. Het is uit deze nebuleuze dat de terroristen voortkwamen die de novemberaanslagen in Parijs en de maartaanslagen in Brussel hebben uitgevoerd. ${ }^{21}$

\subsection{Een globale strategie en uitvoering}

Toen vanaf 2011 een aantal jonge individuen vertrok uit België om deel te nemen aan de gewapende strijd in Syrië, werd dit nog niet ervaren als sterk problematisch. Het ging tenslotte om foreign fighters, die er vooral op uit waren zich te mengen in een militair conflict, gericht op het verwerven van territoria in het buitenland. Vanaf 2012 begon men zich echter in België (en elders in Europa) te rea-

20 M. Eeckhaut, 'Verviers, de mislukte repetitie voor Parijs', De Standaard 14 januari 2016, te raadplegen via: www.standaard.be/cnt/dmf20160113_02066174.

21 T. Renard, 'After Paris and Brussels: reassessing ISIS's strategy in Europe, 8 april 2016', te raadplegen via: www.aspistrategist.org.au/after-paris-and-brussels-reassessing-isiss-strategy-ineurope/. 
liseren dat er iets anders aan de hand was, en stelde men de terugkeer vast van returnees naar Europa als getrainde terroristen.

In oktober 2015 stonden er, volgens de Belgische minister van Binnenlandse Zaken Jan Jambon (N-VA, Vlaams-nationalisten), niet minder dan 837 individuen op te lijst van de Belgische inlichtingendiensten, van wie er 273 naar Syrië of Irak reisden. België scoorde op dat moment het hoogst in de lijst van landen van de Europese Unie met het meeste aantal Syrië-gangers per capita. ${ }^{22}$ Daarvan zouden er intussen 80 gesneuveld zijn aan het front, 134 zouden echter zijn teruggekeerd. ${ }^{23}$ In vele gevallen konden zij bij hun terugkeer onder de radar blijven van justitie en politie en de november- en maartaanslagen voorbereiden en plegen.

Ondanks het vele speurwerk en de navolgende grootschalige processen had een louter strafrechtelijke aanpak niet geleid tot het voorkomen van verdere terreurdaden. Dit verplicht ons ernstige vragen te stellen over de effectiviteit van een louter strafrechtelijke benadering van het terreurfenomeen. ${ }^{24}$ Ondanks uitstekend speurwerk van de politiediensten, de hardnekkigheid van het Belgisch federaal parket en de doortastendheid van de rechtbanken in de hiervoor genoemde drie cases is men er niet in geslaagd het terrorisme waarmee we kennismaakten in Parijs en Brussel te voorkomen. Dit is in grote mate te wijten aan het feit dat velen weliswaar werden veroordeeld, verstek lieten gaan en hun activiteiten elders of clandestien verder hebben gezet. Een louter strafrechtelijke aanpak is dus niet voldoende geweest. Wat dan met een bestuurlijk-preventieve aanpak? Om hier een antwoord op te kunnen geven keren we terug naar ons uitgangspunt: Molenbeek en het 'Brusselse gewest'.

\section{De Belgische staatsconstructie en de politieke gevolgen ervan}

België is een federaal land. Dat is geen toeval. Het land heeft drie officiële talen. Ongeveer $60 \%$ van de bevolking spreekt Nederlands, $40 \%$ spreekt Frans en $1 \%$ spreekt Duits (Oostkantons). Die diversiteit heeft tot een opeenvolging van staatshervormingen geleid, die het land bestuurlijk behoorlijk complex hebben gemaakt. ${ }^{25}$ Intussen heeft België reeds de zesde staatshervorming achter de rug. ${ }^{26}$

In totaal beschikt België over zes regeringen: de federale regering, de Vlaamse regering, de Waalse gewestregering, de Franstalige gemeenschapsregering, de

B. van Ginkel \& E. Entenmann (red.), The Foreign Fighters - Phenomenon in the European Union Profiles, Threats \& Policies (ICCT Research Paper), Den Haag: ICCT 2016.

23 Verenigde commissies voor Justitie en voor Binnenlandse Zaken, Algemene Zaken en het Openbaar Ambt van woensdag 2 december 2015.

24 P. Ponsaers \& E. Devroe, 'De dilemma's van beleidsregimes bij "high impact crime" in Europese metropolen', Strafblad, 2, p. 131-138.

25 E. Devroe, 'Het kopje naast het schoteltje. Over de gestructureerde versnippering in het integrale veiligheidsbeleid', Cahiers Politiestudies 2014, 30, p. 159-181.

26 J. Vanpraet, De latente staatshervorming, Brugge: Die Keure 2011. 
Duitstalige gemeenschapsregering en de regering van het Brussels Hoofdstedelijk Gewest.

Er bestaat uiteraard nog steeds een overkoepelende federale regering voor het gehele grondgebied, vooral bevoegd voor de autoriteitsdepartementen als Defensie, Justitie en Binnenlandse Zaken. De huidige federale regering kwam tot stand na de verkiezingen van 25 mei 2014. Hier is een nooit eerder vertoonde centrumrechtse coalitie aan het bewind van liberalen (MR en Open Vld), christendemocraten $(C D \& V)$ en Vlaams-nationalisten (N-VA). De regeringsformatie duurde niet minder dan 139 dagen. Dit is in grote mate te wijten aan het overweldigende verkiezingssucces dat N-VA boekte. ${ }^{27}$ Opvallend is dat de enige Franstalige partij in de federale regering de MR is. Daar staan diverse partijen tegenover aan Vlaamse zijde, zoals N-VA, CD\&V en Open Vld. De regering wordt geleid door eerste minister Charles Michel (MR). Hij volgde de Franstalige socialist Elio Di Rupo op als regeringshoofd, waardoor een einde kwam aan ruim 25 jaar aanwezigheid van (Franstalige) socialisten in de regering. Als minister van Veiligheid en Binnenlandse Zaken, ook belast met grotestedenbeleid, trad Jan Jambon aan (N-VA). Het ministerie van Justitie viel toe aan Koen Geens (CD\&V). Het zijn deze ministers die het politieel beleid vorm geven. Minister van Defensie werd Steven Vandeput (N-VA).

Daarnaast telt het land drie zogenoemde gewesten (het Vlaamse, het Waalse en het Brusselse). Gewesten zijn verantwoordelijk voor de zogeheten grondgebonden bevoegdheden, zoals economie, werkgelegenheid en openbare werken. Het land telt tevens drie zogenoemde gemeenschappen (het Vlaamse, het Franse en het Brusselse). Gemeenschappen zijn verantwoordelijk voor de persoonsgebonden materies, zoals onderwijs, cultuur en welzijn. De Vlaamse gemeenschap en het Vlaamse gewest hebben een gemeenschappelijk parlement en regering, beide met zetel te Brussel. De Vlaamse regering (gewest en gemeenschap), onder leiding van Geert Bourgeois (N-VA), wordt gevormd door dezelfde Vlaamse partijen (Open Vld, CD\&V en N-VA) als deze die deel uitmaken van de federale regering. Er is met andere woorden van Vlaamse zijde een grote symmetrie tussen de federale regering en de Vlaamse.

In Franstalig België liggen de zaken ingewikkelder. De Franstaligen beslisten om hun afzonderlijke bestuursorganen, namelijk het Waals gewest (zetel te Namen) en de Franse gemeenschap (zetel te Brussel), gescheiden te houden. Traditioneel is de PS (Parti Socialiste) in Franstalig België de grootste partij. De Waalse gewestregering wordt geleid door de Franstalige socialist Paul Magnette (PS) en is een coalitie van Franstalige socialisten (PS) en Franstalige christendemocraten (cdH). Hier is dus hoegenaamd geen symmetrie met de federale regering.

Anderzijds wordt de Franstalige gemeenschapsregering geleid door de Franstalige socialist Rudy Demotte (PS), en de coalitie is dezelfde als deze van de Waalse

27 P. Popelier e.a., België, quo vadis? Waarheen na de zesde staatshervorming, Mortsel: Intersentia 2012. 
gewestregering. Sinds 2011 noemt deze gemeenschap zich 'Federatie WalloniëBrussel'. Omtrent deze benaming was en is nogal wat discussie tussen Frans- en Nederlandstaligen. Langs Vlaamse kant betwist men deze naam vooral omdat zij een soort fusie van Wallonië en Brussel suggereert die feitelijk onbestaande is.

Het meest gecompliceerd is de situatie in het Brusselse gewest, dat dus geen gemeenschap is. Het Brussels Hoofdstedelijk Gewest heeft een eigen parlement en regering, bevoegd voor gewestmateries. ${ }^{28}$ De Vlaamse en Franse gemeenschappen bleven echter bevoegd voor de eigen 'gemeenschapsmateries' op het territorium van het Brussels gewest. Voor zaken die beide gemeenschappen aangaan, is in het Brussels gewest een specifiek orgaan in het leven geroepen. ${ }^{29}$

De Brusselse Hoofdstedelijke Regering bestaat uit een minister-president, vier ministers (twee Nederlandstalige en twee Franstalige) en drie staatssecretarissen. De leden van de Brusselse Hoofdstedelijke Regering beheren de materies ruimtelijke ordening, stedenbouw, stadsvernieuwing, huisvesting, openbare werken, vervoer, economisch beleid, buitenlandse handel, werkgelegenheid, leefmilieu, energie, plaatselijke besturen, wetenschappelijk onderzoek en externe betrekkingen. ${ }^{30}$ Deze Brusselse regering wordt geleid door minister-president Rudi Vervoort (PS). ${ }^{31}$ In die hoedanigheid is hij onder meer bevoegd voor het stedelijk beleid en veiligheid in de gewestregering. Bij de verkiezingen van mei 2013 volgde hij Charles Picqué (eveneens PS) aan het hoofd van de Brusselse regering op. Vervoort leidt een coalitie tussen socialisten (PS en Sp.a), christendemocraten ( $c \mathrm{dH}$ en $\mathrm{CD} \& \mathrm{~V}$ ), liberalen (Open Vld) en de taalpartij (DéFI, een politieke beweging van Brusselse Franstaligen, ontstaan uit verzet tegen de taalwetten in het Brusselse).

Het Brussels Hoofdstedelijk Gewest vormt in realiteit één demografisch geheel, maar bestaat uit negentien gemeenten met elk een eigen burgemeester. Het gaat om: (1) Brussel-stad (burgemeester PS), (2) Anderlecht (burgemeester PS), (3) Etterbeek (burgemeester MR), (4) Evere (burgemeester PS), (5) Ganshoren (burgemeester kartellijst), (6) Jette (burgemeester $\mathrm{cdH}$ ), (7) Koekelberg (burgemeester MR), (8) Oudergem (burgemeester DéFI), (9) Schaarbeek (burgemeester MR), (10) Sint-Agatha-Berchem (burgemeester cdH), (11) Sint-Gillis (burgemeester PS), (12) Sint-Jans-Molenbeek (burgemeester MR), (13) Sint-Joost-ten-Node (burgemeester PS), (14) Sint-Lambrechts-Woluwe (burgemeester DéFI), (15) SintPieters-Woluwe (burgemeester MR), (16) Ukkel (burgemeester MR), (17) Vorst (burgemeester PS), (18) Watermaal-Bosvoorde (burgemeester Ecolo) en (19) Elsene (burgemeester MR). Het valt op dat de politieke verdeeldheid in het Brussels gewest erg groot is, ondanks het manifeste overgewicht van Franstalige par-

28 K. Meerschaut \& P. De Hert, 'Een integraal veiligheidsbeleid op gewestelijk niveau. Het Brusselse Gewest naderbij bekeken', Rechtsleer \& Doctrine 2008, p. 542-576.

29 P. Delwit \& K Deschouwer, 'Staten-Generaal van Brussel. De Brusselse instellingen', Brussels Studies, Synthesenota 2009, 14.

30 D. Jacobs \& M. Swyngedouw, 'Een nieuwe blik op achtergestelde buurten in het Brussels hoofdstedelijk gewest', Tijdschrift voor Sociologie 2000, 3, p. 197-227.

31 R. Vervoort, 'Politieke beleidsverklaring van de regering van het Brussels hoofdstedelijk gewest', 22 oktober 2015. 
tijen. Vooral de rivaliteit tussen de Franstalige PS (gesteund door haar gewest- en gemeenschapsregering) en de Franstalige MR (gesteund door de federale regering) is opmerkelijk.

\section{Het verknipte lokale politiebeleid in het Brussels gewest}

Deze staatsstructuur heeft een aantal gevolgen op het vlak van veiligheid in het Brussels Hoofdstedelijk Gewest. Op de eerste plaats is het zo dat de federale autoriteitsdepartementen van Binnenlandse Zaken (op de eerste plaats) en van Justitie (in bijkomende orde) zeggenschap hebben over de politie. Deze politie is verdeeld in één federale politie en 195 zonale korpsen ${ }^{32}$ sinds de grootschalige politiehervorming van 1998. De federale politie wordt vooral vanuit Binnenlandse Zaken aangestuurd. De lokale wordt voorzien van federale kaderwetgeving, die via tussenliggende overlegstructuren vooral door de gemeentelijke overheden wordt aangestuurd. Kortom, de politiematerie is bij uitstek federale en gemeentelijke materie en geen 'gewestelijke' zaak. ${ }^{33}$ Kortom: het is veeleer de dualiteit fede$\mathrm{raal} /$ gemeentelijk die de politiedynamiek bepaalt dan de dualiteit federaal/gewestelijk. Dit wordt sterk in de hand gewerkt door het feit dat de burgemeester in België politiek verantwoordelijk is voor de activiteiten van 'zijn' korps. Hij kan, in tegenstelling tot Nederland, ${ }^{34}$ onmogelijk deze bevoegdheid delegeren naar een van zijn schepenen. ${ }^{35}$

Sinds de politiehervorming in 1998 is het Brussels Hoofdstedelijk Gewest onderverdeeld in zes politiezones, elk met een andere capaciteit. De grootste zone is (1) PZ Brussel Hoofdstad/Elsene. Hier staat één politieambtenaar in voor slechts 107 inwoners, waarmee dit korps het sterkst scoort in het Brusselse gewest. Verder zijn er: (2) de PZ Brussel-West met Sint-Jans-Molenbeek, Koekelberg, Jette, Ganshoren en Sint-Agatha-Berchem. De omringingscoëfficiënt is in deze zone het minst voordelig, vergeleken met alle andere Brusselse politiezones, met name één inspecteur per 245 inwoners; (3) de PZ Zuid, met Anderlecht, Vorst en Sint-Gillis, met één politieman per 215 inwoners; (4) de PZ Ukkel/Watermaal-Bosvoorde/ Oudergem, met een omringingscoëfficiënt van één politieambtenaar per 237 inwoners; (5) de PZ Montgomery, met Etterbeek, Sint-Lambrechts-Woluwe en Sint-Pieters-Woluwe, met één politieambtenaar voor 211 inwoners; en (6) de PZ

32 Dit aantal is momenteel (2016) teruggebracht tot 189 door een aantal vrijwillige fusie-operaties.

33 P. Ponsaers \& E. Devroe, 'De toekomst van Europese nationale politiebestellen?', in: P. Ponsaers e.a.(red), Toekomstpolitie, Triggers voor een voldragen debat, Antwerpen/Apeldoorn: Maklu 2015, p. 45-85.

34 R. Prins \& L. Cachet, 'Integrale veiligheidszorg en de burgemeester', Tijdschrift voor Veiligheid 2011, (1, p. 43-58.

35 P. Ponsaers \& S. De Kimpe, Consensusmania - Over de achtergronden van de politiehervorming, Leuven/Leusden: ACCO 2001. 
Polbruno, met Evere, Sint-Joost-ten-Node en Schaarbeek, met één agent per 188 inwoners. ${ }^{36}$

In een openhartig interview herinnert voormalig minister van Binnenlandse Zaken en architect van de politiehervorming in 1998, Louis Tobback (Sp.a), aan de reden waarom deze zes politiezones werden ingericht:

'We hebben het ijzer gesmeed toen het heet was. De politiehervorming was voorbereid en de Dutrouxcrisis brak de laatste weerstand. Behalve voor Brussel, dat was echt miserie. Lodewijk de Witte, de huidige gouverneur van Vlaams-Brabant, had een nota over de politiehervorming voorbereid tijdens de onderhandelingen over het Octopusakkoord. ${ }^{37}$ We waren met acht partijen in een middag akkoord. Maar voor Brussel moesten we nog eens terugkomen. De nota ging uit van één politiezone in Brussel, maar het werden er uiteindelijk zes. Dat was een zware toegeving voor de Franstaligen. Hun voorkeur ging uit naar 19 politiezones, want ze wilden hun pretoriaanse wacht behouden.' 38

Daarenboven is het zo dat het Belgische politieconcept nog steeds wezenlijk gestoeld is op een tweedeling tussen 'gerechtelijke' en 'administratieve' politie, die we kunnen beschouwen als een erfenis uit de napoleontische periode. ${ }^{39}$ Deze tweedeling werkt niet alleen door op het niveau van de federale politie, maar ook op dat van de zonale politie. De gerechtelijke politie functioneert in grote mate onder supervisie van Justitie, de administratieve politie onder Binnenlandse Zaken. Onder 'gerechtelijke politie' wordt dan alles beschouwd dat te maken heeft met het vaststellen, opsporen en ophelderen van crimineel gedrag, zeg maar recherche-opdrachten. Deze verlopen onder leiding en toezicht van de magistratuur. Onder 'administratieve politie' wordt alles beschouwd dat te maken heeft met openbare-ordehandhaving en politiële preventie (surveillance en toezicht). Deze activiteiten verlopen onder de bevoegdheid van de bestuurlijke overheden, in essentie de minister van Binnenlandse Zaken (federaal) en de burgemeesters (lokaal). In dit opzicht is de situatie in Nederland, met een tot één gemaakt departement van Veiligheid en Justitie, en een tot één gemaakte Nationale Politie, fundamenteel verschillend, omdat de tweedeling tussen 'gerechtelijke' en 'administratieve’ politiële opdrachten niet langer als zodanig wordt ervaren.

Opnieuw wordt deze tweedeling opgevangen door middel van overleg tussen gerechtelijke en bestuurlijke overheden. In essentie worden die vormgegeven

36 Comité P, Toezichtsonderzoek naar de inzet van de politiecapaciteit in bepaalde wijken van Anderlecht en Sint-Jans-Molenbeek teneinde de veiligheid (leefbaarheid) van de burgers te waarborgen (tussentijds verslag), 27 oktober 2011.

37 Het Octopusakkoord was het politieke akkoord over de hervorming van de politie en het gerecht in België in 1998. De naam 'octopus', letterlijk achtarm, verwijst naar het feit dat er acht politieke partijen bij betrokken waren.

38 X, 'Louis Tobback: Fusie politie in Brussels komt er pas over Reynders lijk', De Tijd 2 april 2016.

39 P. Ponsaers \& E. Devroe, 'Nationale politiebestellen in beweging in Europa', in: Handboek politiediensten, Internationaal, Mechelen: Kluwer 2014, p. 41-98. 
doorheen de vaststelling van het 'Federaal Veiligheidsplan' enerzijds en het 'Zonaal Veiligheidsplan' anderzijds. Beide soorten van plannen zijn voorzien in de Wet op de 'Geïntegreerde Politie, gestructureerd op twee niveaus' en behelzen met andere woorden de puur politiële aangelegenheden die te maken hebben met het zogenoemde 'ketenbeleid' (afstemming tussen bestuurlijke en gerechtelijke prioriteiten van de politie). Deze plannen laten dan ook niet toe te komen tot doortastend integraal veiligheidsbeleid, waarbij gestreefd zou kunnen worden naar samenwerking en partnership tussen diverse instanties van niet-politiële en -gerechtelijke aard.

Kortom, burgemeesters zijn in grote mate afhankelijk van de federale regering om hun politiebeleid vorm te kunnen geven. ${ }^{40}$

\subsection{De aanpak van de oorzaken van de radicalisering in het Brussels gewest}

Met een boutade kan men zeggen dat de repressieve functies van de politie verenigd zijn in één federale hand, maar dat de sociaal-preventieve aspecten (de oorzaken van criminaliteit en radicalisering, met name die aspecten die de weerbaarheid ertegen verhogen, zoals tewerkstelling, onderwijs, sociale huisvesting, welzijn enzovoort) in grote mate tot de bevoegdheden behoren van de gewesten en gemeenschappen. Dat is overigens ook het geval met alle zorg-, hulpverleningsen welzijnsaspecten. Intussen is immers de minister-president van het Brussels gewest sinds 1 juli 2014, als gevolg van de zesde Belgische staatshervorming, bevoegd voor veiligheid.

Vanuit dat oogpunt is een integraal veiligheidsbeleid in een federaal land als België dan ook onvermijdelijk steeds voorwerp van bijzonder veel overleg tussen overheden op diverse beleidsniveaus. ${ }^{41} \mathrm{Er}$ is al een Kadernota Integrale Veiligheid $^{42}$ (KIV) nodig om het beleid op federaal niveau af te stemmen op dat van de gewesten en gemeenschappen. Een dergelijke kadernota wordt dan vooral een oefening om wederzijds elkaars beleidsdomein af en op te lijnen. ${ }^{43}$ Een doortastend integraal veiligheidsbeleid kan hier bezwaarlijk uit voortvloeien. ${ }^{44}$

Zo verklaart de korpschef van de zone Brussel-West, waarin de gemeente Molenbeek gelegen is: 'Staar u niet blind op de lokale politie, wij zijn maar één speler. Er is bijvoorbeeld geen overleg tussen de tientallen verenigingen die in Molenbeek met jongeren werken. De ene wordt gesteund vanuit het Brussels Gewest, de

40 E. Devroe \& P. Ponsaers, 'Reforming the Belgian police system between central and local', in: N.F. Fyfe, J. Terpstra \& P. Tops (red.), Centralizing forces? Comparative perspectives on contemporary police reform in northern and western Europe, Den Haag: Boom Juridische uitgevers/Eleven 2013, p. 77-98.

41 E. Devroe, A swelling culture of control. De genese en de toepassing van de wet op de administratieve sancties in België, Antwerpen/Apeldoorn: Maklu 2012.

42 Pas in juni 2016 door de federale regering naar buiten gebracht, terwijl de regering in oktober 2014 reeds van start ging.

43 W. Bruggeman, 'Nationaal veiligheidsbeleid: eindelijk opnieuw geïntegreerd?', Panopticon 2016, 2, p. $145-152$.

44 P. Ponsaers, 'De communautarisering of de deconstructie van de soevereine staat', Panopticon 2016, 4, p. 249-259. 
andere vanuit de Vlaamse Gemeenschap. Ze houden zich allemaal met hetzelfde bezig, maar er is geen coördinatie.' 45 Didier Gosuin (DéFI, het vroegere FDF), de Brusselse minister van Werk en Economie, slaat in dit verband mea culpa in een interview dat daags na de aanslagen in Brussel werd afgenomen: 'We zijn blind geweest voor een hele groep jongeren die zich afkeerde van de samenleving.' Op de vraag of er een link is tussen de hoge jeugdwerkloosheid en moslimradicalisering moet de minister het antwoord schuldig blijven:

'Dat is moeilijk te zeggen, maar ik ben ervan overtuigd dat zaken als sectarisme [sic] en radicalisme een kans krijgen in een samenleving die geen hoop geeft aan mensen. Mensen hebben altijd de behoefte om ergens in te geloven, ook al is het een leugen. De beste wapens tegen radicalisme en extremisme zijn onderwijs, vorming, stages en de persoonlijke begeleiding van werklozen. De Brusselse overheid heeft die zaken jarenlang verwaarloosd, in elk geval niet krachtdadig genoeg aangepakt. Er is onvoldoende in het Franstalige onderwijs geïnvesteerd en dat is de fout van de Franstalige partijen.' ${ }^{46}$

Burgemeesters zijn met andere woorden in grote mate afhankelijk van de deelregeringen om hun sociaal-preventieve veiligheidsbeleid op hun grondgebied in het Brussels Hoofdstedelijk Gewest te kunnen boetseren. In dat gewest blijkt dat een bijzonder moeilijk gegeven omwille van de politieke verdeeldheid, die juist hier uitgesproken tot uiting komt.

\subsection{Het federale 'kanaalplan' en het gewestelijke 'preventieplan' als illustratie}

De kritiek op de organisatie van de politie in Brussel nam toe na de aanslagen van 22 maart 2016 op de luchthaven van Zaventem en het metrostation Maalbeek. Diverse commentatoren wezen op de versnippering van het politie- en politiek landschap in het Brussels Hoofdstedelijk Gewest, met zes politiezones en negentien gemeenten in één demografische geheel. De Belgische premier Charles Michel reageerde op 2 april 2016 laconiek in enkele interviews en stelde: 'Ik ken geen taboes. Maar ik heb niet de indruk dat er in Zaventem twee bommen zijn ontploft omdat Brussel zes politiezones telt (...) Ik hou niet vast aan structuren als hun meerwaarde niet bewezen is (...) Maar vandaag lijkt zo'n aanpassing mij geen prioriteit. ${ }^{47}$

De discussie over de versnippering in het Brusselse gewest dateert echter van vroeger dan 22 maart 2016. Ze stak de kop op naar aanleiding van de voorstelling van het federale 'kanaalplan' in januari 2016, als antwoord op de gebeurtenissen in Parijs op 13 november 2015. ${ }^{48}$ Volgens het 'kanaalplan' moeten er dit jaar reeds 300 bijkomende politiemensen ingezet worden. Dit strekt zich uit over de

47 K. Heylen, 'Premier Michel vindt fusie politiezones geen dringende prioriteit', De Redactie.be 2 april 2016.

48 Ch. Degreef, ‘Grote lijnen kanaalplan Jambon bekend’, Brussel deze Week 27 januari 2016. 
gemeenten Molenbeek, Vilvoorde, ${ }^{49}$ Anderlecht, Koekelberg, Laken, ${ }^{50}$ Schaarbeek, Sint-Gillis en Sint-Joost-ten-Node, samen goed voor een investering van 39 miljoen euro.

Het is merkwaardig dat het 'kanaalplan' opteert voor samenwerking tussen deze gemeenten en daarbij Brussel-stad buiten beschouwing laat, waarvan slechts een beperkt onderdeel participeert, met name de deelgemeente Laken. Verder valt op dat dit federaal plan zich richt op samenwerking op gemeentelijk niveau en niet op samenwerking tussen politiezones. Het plan doorsnijdt als het ware de politiestructuur zoals deze bij de hervorming van 1998 werd ingesteld, ten voordele van een alliantie tussen burgemeesters van specifieke gemeenten. ${ }^{51}$ Sinds 2013 wordt het ambt van burgemeester in Brussel-stad waargenomen door de Franstalige socialist Yvan Mayeur (PS), die in het verleden in aanvaring kwam met Jambon, ${ }^{52}$ zodat niet valt uit te sluiten dat politieke motieven aan de concrete invulling van het plan ten grondslag hebben gelegen

De meest urgente maatregelen in het 'kanaalplan' hebben betrekking op Molenbeek en Vilvoorde. Molenbeek kreeg er meteen vanaf 1 februari 2016 in een eerste fase 50 politiemensen bij en Vilvoorde 20. Het gaat om federale personeelsleden die toegevoegd worden aan de lokale politiezones. De coördinatie zal worden waargenomen door de korpschef van zone Brussel-West/Molenbeek en de Brusselse directeur-coördinator van de federale politie. Het 'kanaalplan' kende een eerder pruttelende start omwille van weerstanden vanwege de weerstand bij de politiebonden.

Rond dezelfde periode, op 21 januari 2016, stelde de Brusselse minister-president van het Brusselse gewest, Rudi Vervoort (PS), een preventie- en bestrijdingsplan voor dat hij voorbereidde met de burgemeesters van Brussel-stad, Schaarbeek, Anderlecht en Molenbeek. Vervoort stelt zijn gemeenten een globale aanpak voor van het radicalisme. Het is de bedoeling om via dit instrument van zo nabij mogelijk in te spelen op de behoeften die geformuleerd worden door de gemeenten en de inwoners van het Gewest zonder te discrimineren of te stigmatiseren. Er wordt sterk ingezet op beleidsdomeinen zoals onderwijs, jeugdhulp, opleiding, tewerkstelling, huisvesting en sociale cohesie.

Beide plannen, het 'kanaalzone'-plan van het federale departement Binnenlandse Zaken en dat van het Brusselse gewest, houden geen enkele verwijzing naar elkaar in.

49 Vilvoorde maakt geen deel uit van het Brussels gewest, maar ligt wel langs de kanaalzone en telt 28 gekende Syrië-gangers.

50 Laken is geen zelfstandige gemeente in het Brusselse gewest, maar een onderdeel van de stad Brussel.

51 P. Ponsaers \& E. Devroe, 'Het kanaalplan, het aanhouden van het verhoogde dreigingsniveau en de sluipende privatisering', Cahier Politiestudies 2016, 39, p. 213-237.

$52 \mathrm{Na}$ de nationale vakbondsbetoging in Brussel op 6 november 2014 kwam er veel kritiek op Mayeur, onder andere uit zijn eigen politiekorps. Hij kwam in botsing met N-VA-voorzitter Bart De Wever, tevens burgemeester van Antwerpen, en de minister van Binnenlandse Zaken, Jan Jambon (eveneens N-VA). 


\section{Conclusie}

In deel 1 van deze bijdrage stelden we vast dat de strafrechtelijke aanpak van radicalisering en terrorisme weinig structureels heeft bijgedragen aan het reëel terugdringen van deze problemen. In deel 2 stelden we vast dat de Belgische staatsstructuur en de permanente hervorming ervan als het ware een tweesporenbeleid deed ontstaan, waardoor de sociaal-preventieve functie van de gewesten en gemeenschappen los kwam te staan van de federale handhavende en misdaad bestrijdende politiefunctie. Dit tweesporenbeleid bemoeilijkt sterk het implementeren van een reëel integraal veiligheidsbeleid, waarbij het bestrijden van de oorzaken van radicalisering gelijk opgaat met de strafrechtelijke aanpak ervan.

Een waarachtig IV-beleid beschouwt de politie als een van de partners in het brede maatschappelijke middenveld die de oorzaken van criminaliteit, onrust en sociale wanorde trachten te beheersen. Community policing houdt in die zin een essentiële preventieve opdracht in: het voorkomen dat er zich problemen verdichten in bepaalde groepen of op specifieke plaatsen, en de ambitie om bij te dragen aan het terugdringen van de oorzaken ervan.

Molenbeek en het hele Brusselse gewest zijn zwaar getroffen gedurende de afgelopen jaren. Om hieraan te verhelpen moet, daar waar het gaat om radicalisering van jongeren, de voedingsbodem van die radicalisering worden tegengegaan. Heel concreet komt dat neer op het verschaffen van tewerkstelling, van degelijk onderwijs en sociale huisvesting, van bijstand en zorg. Uiteraard is dat niet de uitsluitende opdracht van de politie, maar is dat een gemeenschappelijke opdracht van de publieke overheid, tot op grote hoogte van het gemeentelijk beleid. Buurthuizen, straathoek- en jeugdwerkers, opvoeders, inburgerings- en hulpverleningscentra en vele anderen moeten daartoe bijdragen, samen met diverse gemeentelijke diensten.

Waaruit blijkt dat? Na de Charlie Hebdo-aanslagen in Parijs van januari 2015 bleek een van de jongeren op een Brusselse school te sympathiseren met de terroristen. De leraren werden ongerust en probeerden dit te melden, maar er bleek geen gereglementeerd communicatiekanaal aanwezig te zijn. Enige tijd later vertrok de jongeman naar Syrië. Het Belgische Openbaar Ministerie wist dat hij naar Syrië was vertrokken, maar was niet op de hoogte van zijn terugkeer. In november 2015 blijkt hij een van de zelfmoordterroristen te zijn die zich opblies aan het Stade de France te Parijs.

De grondgedachte bij de politiehervorming van 2001 was in grote mate de politiele werking nauw te laten aansluiten op het gemeentelijke beleid, zodat precies het hiervoor genoemde 'integraal veiligheidsbeleid' reële kansen kreeg. De ervaring leert dat een evenwichtig integraal veiligheidsbeleid een lange adem heeft en slechts resultaten oplevert wanneer het geschraagd wordt door verschillende partners met elk een eigen rol en verantwoordelijkheid. Dat is momenteel niet mogelijk in Brussel. Het is dan ook niet verwonderlijk dat het jaarverslag 2014 van het Comité $\mathrm{P}$, in tempore non suspecto, waarschuwde voor een groeiende 
kloof tussen politie en bevolking in een aantal politiezones in Brussel, onder meer in Molenbeek. ${ }^{53}$

Het hernemen van het oude voorstel van samensmelting van de zes politiezones van het Brussels Hoofdstedelijk Gewest is op zich best verdedigbaar, en onzes inziens zelfs noodzakelijk, indien dit echter gepaard gaat met de samenvoeging van de negentien Brusselse gemeenten tot één bestuursniveau of één stedelijk gebied. Het is slechts op deze manier dat een 'integraal veiligheidsbeleid' ook in Brussel vorm kan worden gegeven. Het creëren van één Brusselse politiezone, zonder te raken aan de negentien afzonderlijke gemeenten, kan echter enkel maar tot een grotere afstand tussen het bestuur en de politie leiden, en meteen ook tot minder gemeenschapsgerichtheid. ${ }^{54}$

Het voorstel van de Brusselse $C D \& V$-parlementsleden Grouwels en Delva, die pleiten voor een 'regeringscommissaris tegen terreur' voor Brussel onder de minister van Binnenlandse Zaken, steunt op het Parijs model, waar de Parijse politieprefect de nationale politie in de stad aanstuurt vanuit het centralistisch departement Binnenlandse Zaken. ${ }^{55}$ In een dergelijk model wordt het gesignaleerde tweesporenbeleid echter enkel maar versterkt. Het weerspiegelt immers de dominante beleidsopvatting die politici hebben over de 'ware aard' van het politiewerk, met name misdaadbestrijding. Nochtans weten we dat de invloed van de politie op criminaliteit, radicalisering en terreur zeer beperkt is, omdat de oorzaken ervan zich buiten de invloedssfeer van de politie bevinden.

In die zin is de Duitse oplossing dan ook sterk het overwegen waard. ${ }^{56}$ De federale Duitse Bondsrepubliek heeft voor de hoofdstad Berlijn immers een bijzondere regeling uitgewerkt, die erop neerkomt dat de president van de deelstaat Berlijn meteen ook de functie van burgemeester van de stad Berlijn opneemt. ${ }^{57}$ Op deze wijze heeft hij tezelfdertijd greep op het politieel optreden als op het sociaal-preventieve beleid in de metropool. Een dergelijke oplossing komt tegemoet aan de bezwaren die in het voorgaande werden genoemd, het blijkt werkbaar in een federaal land én is toepasbaar in het Brussels gewest.

Maar dat impliceert meteen ook dat niet enkel de zes politiezones worden gefusioneerd, maar tevens dat de negentien Brusselse burgemeestersposten worden ingeruild voor één. Pas op dat moment kan er een ware afstemming zijn tussen misdaadbestrijding en bestuurlijk beleid in Brussel-19 en het Brussels gewest. Enkel met de samenvoeging van de zes politiezones raakt het probleem niet van de baan. Daarvoor is echt wel meer nodig.

54 P. Ponsaers e.a., 'Bestellen en Schalen', Orde van de Dag 2012, 57, p. 6-11.

55 'Geef Brussel regeringscommissaris tegen terreur', De Morgen 8 april 2016.

56 P. Ponsaers e.a., 'Policing European Metropolises', in: P. Ponsaers e.a. (red.), European Journal of Policing Studies (Special Issue Policing European Metropolises) 2014, 1, p. 3-13.

57 H. Aden \& E. De Pauw, 'Policing Berlin. From separation by the iron curtain to the new German capital and a globalised city', European Journal of Policing Studies (Special Issue Policing European Metropolises) 2015, 1, p. 13-30. 


\section{Afkortingen politieke partijen}

\begin{tabular}{ll}
\hline cdH: & Franstalige christendemocraten \\
CD\&V: & Nederlandstalige christendemocraten \\
DéFI: & Franstalige taalpartij (voorheen FDF) \\
Ecolo: & Franstalige ecologisten \\
Groen: & Nederlandstalige ecologisten \\
MR: & Franstalige liberalen \\
N-VA: & Vlaams-nationalisten \\
Open VId: & Nederlandstalige liberalen \\
PS: & Franstalige socialisten \\
Sp.a: & Nederlandstalige socialisten \\
\hline
\end{tabular}

